\title{
Pemberitaan Media Cetak dalam Mempengaruhi Partai Politik untuk Menentukan Calon pada Pemilukada Tahun 2015
}

\author{
Hairul Iman Hasibuan \\ Persatuan Wartawan Indonesia Tabagsel, P. Sidempuan, Indonesia \\ Koresponden: hairulhsb@gmail.com
}

\begin{abstract}
ABSTRAK
Penelitian ini bertujuan untuk mengetahui bagaimana media cetak mempengaruhi partai politik menentukan siapa calon yang diusung pada Pemilukada di Kabupaten Tapanulis Selatan tahun 2015. Peneliti mengkaji isi pemberitaan dua media cetak lokal yakni Harian Analisa dan Harian Waspada. Metode yang digunakan adalah deskriptif dengan pendekatan kualitatif yaitu menganalisis dan mendiskripsikan pendapat para partisipan pada tiga partai politik. Tiga partai politik tersebut yaknin Partai Golkar, PPP dan Partai Gerindra. Berdasarkan penelitian diketahui dan menghasilkan bahwa media cetak nasional yang terdistribusi di tingkat kabupaten, provinsi, pusat dan memiliki basis pembaca yang besar seperti Harian Analisa dan Harian Waspada menjadi alat ukur partai politik dalam menilai elektabilitas bakal calon bupati yang akan diusungnya pada Pemilukada Tapsel 9 Desember 2015.Selain itu isi berita yang memuat riwayat hidup, visimisi dan kedekatan bakal calon kepala daerah dengan masyarakat menjadi salah satu faktor di luar lobi dan uang yang mampu mempengaruhi partai politik mengusung calon pada Pemilukada Tapsel.
\end{abstract}

Kata Kunci: Media Cetak, Pemilukada, Berita

\begin{abstract}
This study aims to find out how the print media influences political parties to determine who the candidates are carried out in the Regional Head General Election in South Tapanulis Regency in 2015. The researchers examined the contents of the coverage of two local print media namely Harian Analisa and Harian Waspada. The method used is descriptive with a qualitative approach by analyzing and describing the opinions of participants, namely three political parties. The three political parties included: Golkar, PPP and Gerindra parties. Based on research, it is known and produces national printed media distributed at the district, provincial, central level and has a large reader base such as Harian Analisa and Harian Waspada to measure political parties in assessing the electability of candidates for regency in the Tapsel Regional Election on December 9 2015. In addition, the contents of the news that contains the curriculum vitae, vision and mission and the closeness of the candidates for regional heads and the community are one of the factors outside lobbying and money that can influence political parties carrying candidates in the Pemilukada Tapsel.
\end{abstract}

Keywords: Print Media, Election, News

\section{Pendahuluan}

Pemilihan Langsung Umum Kepala Daerah atau biasa disingkat Pemilukada adalah sarana pelaksanaan kedaulatan rakyat di wilayah provinsi dan atau kabupaten/kota berdasarkan Pancasila dan Undang-undang Dasar Negara Republik Indonesia Tahun 1945 untuk memilih Kepala Daerah dan Wakil Kepala Daerah. Pemilihan kepala daerah (Pilkada atau Pemilukada) dilakukan secara langsung oleh penduduk daerah administratif setempat yang memenuhi syarat. Pemilihan kepala daerah dilakukan satu paket bersama dengan wakil kepala daerah. Kepala daerah dan wakil kepala daerah yang dimaksud mencakup: 
gubernur dan wakil gubernur untuk provinsi, bupati dan wakil bupati untuk kabupaten, walikota dan wakil walikota untuk kota.

Pemilukada yang dilaksanakan pada tahun 2015 hanya akan menggunakan sistem satu putaran, yang artinya siapapun calon kepala daerah peraih suara tertinggi maka akan dinobatkan sebagai pemenang sebagaimana diatur dalam Undang-Undang No 8 tahun 2015 tentang Perubahan Atas Undang-Undang Nomor 1 tahun 2015 tentang Penetapan Peraturan Pemerintah Pengganti Undang-Undang Nomor 1 tahun 2014 tentang Pemilihan Gubernur, Bupati, Walikota menjadi Undang-Undang.

Pada hasil perolehan suara pada pemilihan legislatif tahun 2014 hanya tujuh dari dua belas partai politik yang turut sebagai peserta pemilihan legislatif berhasil memperoleh kursi di DPRD Tapsel. Ketujuh partai politik masing-masing yakni Partai Golkar meraih 7 kursi, Gerindra 5 kursi, Nasdem 4 kursi, PAN 3 kursi, PDIP 3 kursi, Hanura 3 kursi, PPP 2 kursi, Demokrat 1 kursi, dan PKPI 1 kursi. Agar dapat memenuhi syarat untuk mengusung calon kepala daerah pada Pemilukada 2014, maka harus memiliki minimal 6 kursi. Hanya partai Golkar satu-satunya yang memenuhi syarat mengusung pasangan calon kepala daerah pada Pemilukada Tapsel 2015. Sementara partai politik yang tidak memenuhi syarat enam kursi yang ingin mengusung calaon pada Pemilukada serentak 2015, maka harus berkoalisi dengan partai politik lain yang memiliki kursi di DPRD.

Kabupaten Tapanuli Selatan atau disebut Tapsel merupakan satu dari empat belas kabupaten/kota di Provinsi Sumatera Utara yang akan menggelar Pemilukada serentak di tahun 2015. Berdasarkan jadwal tahapan Pemilukada Tapsel yang dikeluarkan Komisi Pemilihan Umum hari pelaksanaan Pemilukada Tapsel jatuh pada tanggal 9 Desember. Dalam menghadapi Pemilukada ini maka Parpol yang memiliki kursi di DPRD Tapsel telah mempersiapkan bakal calon yang akan diusung pada tanggal 9 Desember 2015 mendatang. Persiapan itu ditandai dengan dibukanya panitia penjaringan calon kepala daerah dan wakil kepala daerah di Kabupaten Tapsel 2015. Proses penjaringan itu tentu bersifat terbuka kepada seluruh masyarakat yang ingin memakai partai politik untuk ikut berkompetisi pada Pemilukada. Penjaringan ini dimulai dari tingkat daerah (DPD/DPC) kemudian naik ke tingkat provinsi/wilayah (DPW) dan tingkat pusat (DPP). Pada proses ini tentunya para figur yang mendaftar di panitia penjaringan partai politik akan berupa maksimal merebut hati perahu yang akan ditumpanginya pada Pemilukada. Demikian sebaliknya partai politik yang melakukan seleksi kepada para calon kepala daerah akan sangat selektif dalam menentukan satu nama yang akan diusung pada Pemilukada 2015.

Media cetak merupakan media massa yang banyak digunakan para calon kandidat untuk menaikkan nama mereka agar dapat dilirik oleh para partai politik agar dapat mendukung mereka dalam Pemilukada pada tahun 2015 ini. Di Tapsel terdapat tiga basis pembaca pada media cetak yang dijadikan dasar para calon kandidat menarik perhatian para partai politik agar dapat mendukung mereka. Kedua media cetak tersebut adalah:

a. Harian Analisa yang basis pembacanya menengah ke atas. Kebanyakan pembacanya berasal dari etnis Tionghoa.

b. Harian Waspada yang basis pembacanya menengah ke bawah. Kebanyakan pembacanya mayoritas umat Islam 
Penulis tertarik ingin menganalisis media cetak dalam mempengaruhi partai politik menentukan calon pada Pemilukada kabupaten Tapanuli Selatan.

\section{Teori Agenda Setting}

Agenda-setting Theory diperkenalkan oleh McCombs dan Donald Shaw dalam Public Opinion Quarterly tahun 1972, berjudul The Agenda Setting Function of Mass Media.Menurut McCombs dan Shaw (dalam Effendy, 2003: 286), asumsi dasar teori penyusunan agenda (agenda-setting theory) adalah jika media memberi tekanan pada suatu peristiwa, maka media itu akan mempengaruhi khalayak untuk menganggapnya penting.

McCombs dan Donald Shaw (dalam Effendy, 2003: 287) mengatakan pula, bahwa audience tidak hanya mempelajari berita-berita dan hal-hal lainnya melalui media massa, tetapi juga mempelajari seberapa besar arti penting diberikan pada suatu isu atau topik dari cara media massa memberikan penekanan terhadap topik tersebut. Misalnya, dalam merefleksikan apa yang dikatakan oleh para kandidat dalam suatu kampanye Pemilu, media massa terlihat menentukan mana topik yang penting.

\section{Media Cetak}

Sosiawan (2009: 1) menyatakan media cetak adalah media statis dan mengutamakan pesan-pesan visual yang dihasilkan dari proses percetakan; bahan baku dasarnya maupun sarana penyampaian pesannya menggunakan kertas). Media cetak adalah suatu dokumen atas segala hal tentang rekaman peristiwa yang diubah dalam kata-kata, gambar foto dan sebagainya (contoh: surat kabar, majalah, tabloid, brosur, pamflet, poster). Media cetak adalah "meliputi segala barang yang dicetak, yang ditujukan untuk umum atau untuk suatu publik tertentu" (Sosiawan, 2009: 2). Dengan demikian yang dimaksud adalah meliputi surat kabar, majalah, serta segala macam barang cetakan yang ditujukan untuk menyebarluaskan pesan-pesan komunikasi. "Media cetak sendiri pengertiannya adalah media statis yang mengutamakan pesan visual yang terdiri dari lembaran, sejumlah kata gambar atau foto" Sosiawan (2009: 2). Umumnya media cetak adalah media atau bahan sesorang untuk mencari informasi. "Media cetak merupakan suatu dokumen atas segala hal yang ditangkap oleh sang jurnalis dan diubah ke dalam bentuk kata-kata, gambar, foto, dan sebagainya" (Nirmana,1999: 62).

\section{Koran}

Menurut Jhon Tabbel dalam bukunya yang berjudul Karier Jurnalistik, pengertian koran adalah rangkuman dari semua isi berita yang disajikan melalui media cetak sebagai sarana komunikasi massa, dimana koran ini diperuntukkan untuk umum yang menyangkut kepentingan umum, serta berita yang disajikan dalam koran tersusun dalam alinea kalimat yang dicetak pada kertas, sedangkan menurut Frank Jefkin (1994) koran merupakan salah satu media lini atas yang merupakan rangkuman dari semua isi berita yang disajikan melalui media cetak meliputi penempatan komposisi layout. Setiap bentuk layout harus mampu berbicara kepada pembaca lewat tampilan unsur rupa visual seperti: garis, bidang, bentuk warna tipografi, ilustrasi sebagai bentuk kesatuan secara visual.

Beberapa kekuatan koran seperti yang dituliskan oleh Hayun Gunawan dalam skripsinya yang berjudul Kajian Layout Cover Koran Pikiran Rakyat (2003), yaitu:
1. Market Corerage
2. Comporizon Catalog Value
3. Positive Consumen
4. Flexibility 


\section{Partai Politik}

Dalam definisinya, partai politik merupakan sarana bagi warga negara untuk turut serta atau berpartisipasi dalam proses pengelolaan negara. Dimana partai politik adalah suatu kelompok terorganisir yang anggota-anggotanya mempunyai orientasi, nilai-nilai, dan cita-cita yang sama (Budiarjo, 2006: 160).

Dalam bukunya yang berjudul Economic et Societe (1959) Max Weber mendefinisikan partai politik sebagai organisasi publik yang bertujuan untuk membawa pemimpinnya berkuasa dan memungkinkan para pendukungnya untuk mendapatkan keuntungan dari dukungan tersebut. Partai politik adalah organisasi yang bertujuan untuk membentuk opini publik. Sebagai suatu organisasi yang khas, partai politik dilihat sebagai suatu bentuk organisasi yang berbeda dengan organisasi lain (Firmanzah, 2008: 67).

Partai politik dilihat sebagai autonomous groups that make nominations and contest elections in the personel and policies of goverment (Ranney \& Kendall, 1956). Dalam konteks ini, mereka melihat bahwa tujuan utama dibentuknya partai politik adalah mendapatkan kekuasaan dan melakukan kontrol terhadap orang-orang yang duduk dalam pemerintahan sekaligus kebijakannya.partai politik sangat terkait dengan kekuasaan, untuk membentuk dan mengontrol kebijakan publik. Selain itu, partai politik juga diharapkan independen dari pengaruh pemerintah. Hal ini tentunya menyiratkan agar partai politik bisa mengkritisi setipa kebijakan dan tidak tergantung pada pemerintah yang dikritisi (Firmanzah, 2008: 67).

\section{Metode}

Penelitian ini menggunakan pendekatan kualitatif untuk mendapatkan data yang mendalam, suatu data yang mengandung makna. Pendekatan ini secara signifikan dapat mempengaruhi subtansi penelitian. Artinya bahwa pendekatan kualitatif menyajikan secara langsung hakikat hubungan antara peneliti dan informan, objek dan subjek penelitian (Sugiyono, 2012: 3).

Sesuai dengan permasalahan dan tujuan dari penelitian ini, maka penggunaan kualitatif-deskriptif untuk menganalisa, mendeskripsikan pendapat para partisipan penelitian atau informan penelitian yaitu tiga partai politik. Tiga partai politik tersebut antara lain: partai Golkar, PPP, Partai Gerindra. Isi berita Harian Analisa dan Harian Waspada tentang figur calon kepala daerah pada Pemilukada Kabupaten Tapanuli Selatan 9 Desember 2015.

\section{Hasil dan Penelitian}

a. Peranan Media Cetak dalam Mempengaruhi Partai Politik Menentukan Calon pada Pemilukada Kabupaten Tapanuli Selatan 2015. Perhelatan pemilihan umum kepala daerah di Tapanuli Selatan telah dilaksanakan serentak pada tanggal 9 Desember 2015. Pada saat menjelang pemilihan umum kepala daerah tersebut muncullah fenomena politik yang begitu mendominasi pemberitaan pada kolom-kolom media cetak di Tapanuli Selatan, hampir setiap sudut kolom terhiasi oleh beragam pemberitaan mengenai pemilukada Tapanuli Selatan. Hal ini dapat kita lihat pada harian Analisa dan Harian Waspada edisi bulan Mei tahun 2015. Hampir semua tokoh atau figur memanfaatkan media dalam menyampaikan pesan-pesan politiknya, mereka melakukan hal tersebut karena menyadari peranan media sangat kuat sehingga memanfaatkan media sebagai wadah sosialisasi dan juga untuk meraih dukungan serta popularitas di tengah-tengah masyarakat Tapanuli Selatan. Dalam proses pemilihan umum, baik pada tingkat pusat dan daerah, kampanye merupakan salah satu tahapan yang harus dilaksanakan oleh setiap kandidat. 
Kampanye yang dimaksud disini ialah suatu kampanye yang bertujuan untuk memberikan kesempatan kepada para partai politik untuk megenal lebih dalam terhadap tokoh-tokoh yang hendak menjadi kandidat calon di Pemilukada dan mereka berharap para partai politik yang tertarik dapat mendukung mereka untuk selanjutnya menjadi calon pada Pemilukada tahun 2015.

b. Berita politik yang disampaikan dalam media cetak juga merupakan suatu usaha yang terkelola secara terorganisir dan tersturkur untuk menjaring para partai politik guna memilih para kandidat calon Pemilukada. Adapun bentuk dan jenis berita politik yang sengaja disampaikan oleh para tokoh atau figur dalam rangka meraih simpati dan dukungan para partai politik untuk mengusung mereka menjadi calon dalam Pemilukada. Berita politik yang dilancarkan antara lain dilakukan secara persuasif, yang artinya cara berita politik ini disajikan dibagi dalam dua kategori, yakni berita politik yang bersifat informatif dan yang bersifat komunikatif.

c. Adapun pemilihan kata, bahasa dan gambar yang dapat memberikan efek pada ketiga aspek tersebut ialah seperti pemilihan kata yang mampu menyentuh nilainilai kehidupan dan aspek kebudayaan serta psikologis atau emosional seseorang. Pemilihan bahasa juga menjadi salah satu fokus utama dalam menyampaikan pesan-pesan, dimana pemilihan dan penggunaan bahasa perlu memperhatikan unsur-unsur budaya dari daerah setempat (lokasi pemilihan). Pemilihan bahasa juga harus bisa memberikan kemudahan bagi seseorang dalam memahami dan memaknai pesan yang disampaikan.

d. Selain kekuatan ternyata surat kabar memiliki kelemahan, berdasarkan hasil penelitian para ketua DPD partai politik dan tim survei menyadari akan adanya kelemahan pada surat kabar seperti yang diungkapkan oleh Hayun Gunawan dan cara mengatasinya pun hendaknya dalam menyajikan berita disajikan sesuai fakta dan lebih objektifnya jangan mengikuti kepentingan kelompok tertentu. Berdasarkan hasil penelitian pengklasifikasian surat kabar didasari pada basis pembaca yang berstatus lokal, harian, mingguan serta nasional.

e. Keseluruhan ciri, sifat, kekuatan, kelemahan sampai pada klasifikasi surat kabar telah menjadi bahan pertimbangan utama oleh para tim survei dan para Ketua DPD untuk menggunakan media cetak khususnya surat kabar untuk menilai, dan mengevaluasi para calon kandidat yang hendak mancalonkan diri menjadi calon Pemilukada tahun 2015. Melalui media cetak ini lah partai politik menilai sebarapa besar kepopuleran seorang tokoh diata masyarakat Tapanuli Selatan, agar pada saat Pemilukada ini berlangsung diharapkan para pemilih sudah mengenal sosok calon Pemilukada ini dan segera untuk memilih jagoannya masing-masing dan meraih suara sebanyak-banyaknya.

f. Partai Golkar mengusung pasangan Calon Bupati Syahrul M Pasaribu dan wakil Bupati Aswin Effendi Siregar. Pada partai PPP Pasangan calon yang mendaftar ke panitia penjaringan DPD PPP Tapsel ada dua yaitu pasangan Cabup Wacabup Muhammad Yusuf Siregar-Rusyidi Nasution dan Paslon Syahrul M PasaribuAswin Efendi Siregar. Namun akhirnya PPP mengusung Pasangan Calon Syahrul M Pasaribu-Aswin Efendi Siregar. Pada partai Gerindra kandidat yang mendaftar ke panitia penjaringan Gerindra ada 3 yaitu pasangan Muhammad Yusuf SiregarRusyidi Nasution, Syahrul M Pasaribu-Aswin Effendi Siregar, dan Aldinz Rapolo Siregar-Borkat, S.Sos. Namun Gerindra akhirnya mengusung pasangan Syahrul M Pasaribu-Aswin Siregar pada Pilkada Tapsel 9 Desember 2015. Masing-masing 
partai politik berharap perolehan suara yang didapatkan nanti pada Pemilukada dapat sesuai dengan harapan mereka. Tokoh atau figur yang mereka usung didapat melalui penilaian serta evaluasi terhadap pemberitaan pada media cetak, sehingga memang media cetak memiliki peranan yang sangat penting dalam menyampaikan pesan-pesan politik.

b. Analisis muatan atau isi berita yang dapat mempengaruhi partai politik menentukan calon pada Pemilukada Kabupaten Tapanuli Selatan 2015

Keberadaan wartawan dalam dunia jurnalistik tidak dapat dinomorduakan sebagai peliput serta penulis berita. Pada media cetak, terutama surat kabar merupakan salah satu ruang tempat mereka menuliskan hasil liputan terhadap peristiwa-peristiwa yang terjadi di negara ini. Pada pembahasan ini peneliti akan membahas dua berita, yang pertama berita tentang Pemilukada dari Harian Analisa dan yang kedua dari Harian Waspada.

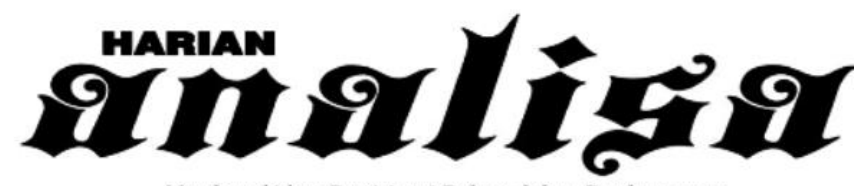 \\ Membangkitkan Partisipasi Rakyat dalam Pembangunan \\ Dua Bakal Calon Bupati Tapsel Resmi Daftar ke PPP}

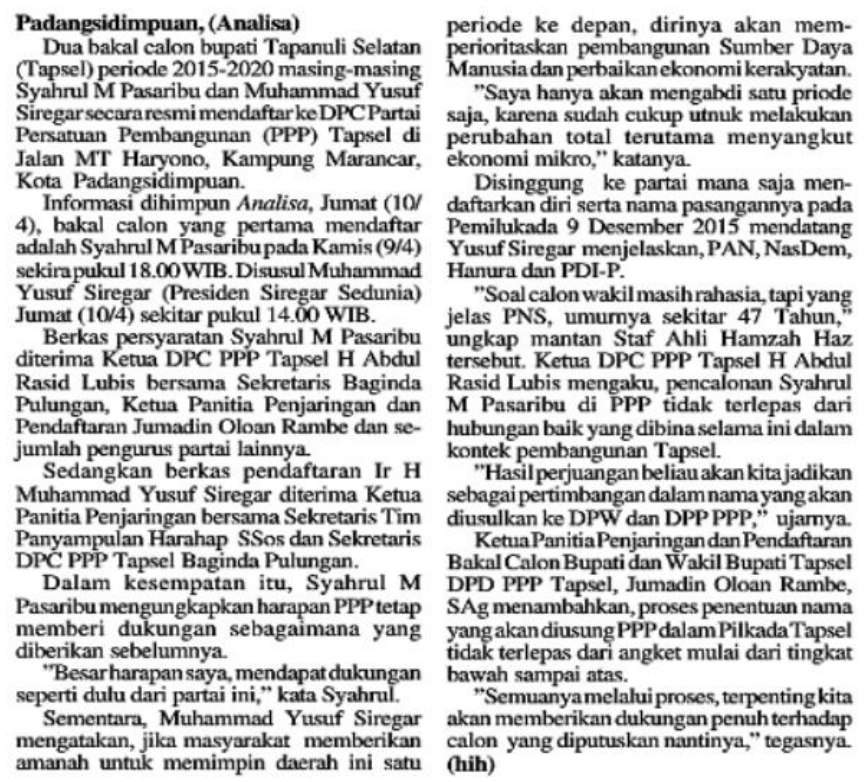

Gambar 1.1. Berita tentang Pemilukada dari Harian Analisa Sumber: Harian Analisa 


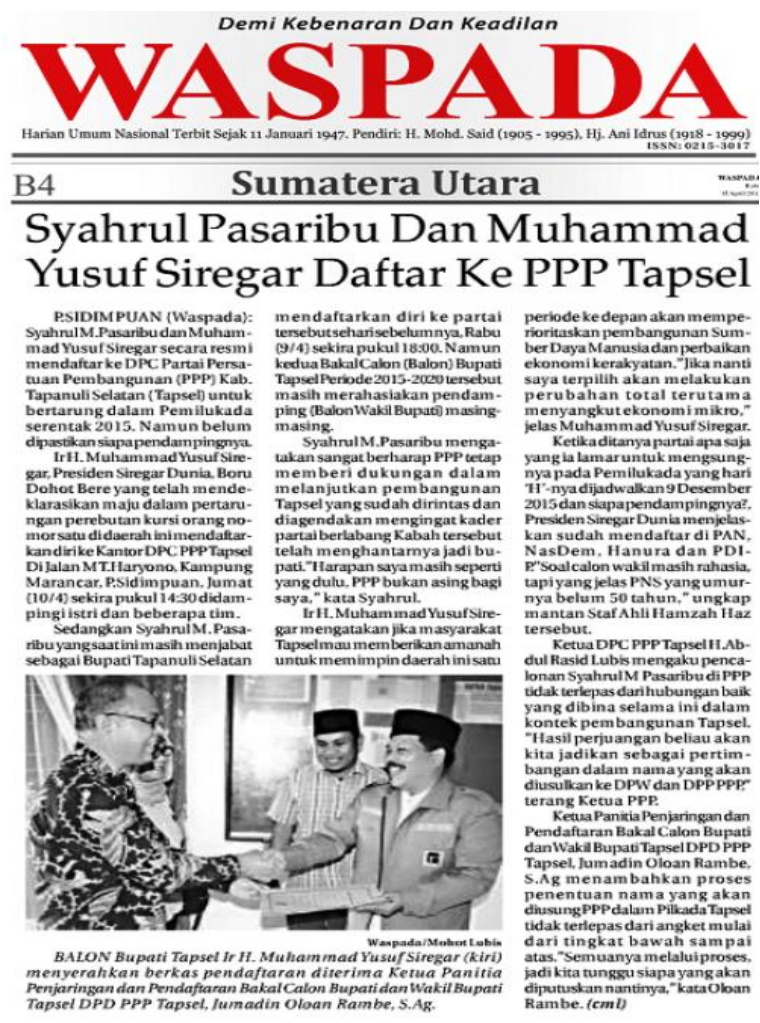

Gambar 1.2. Berita tentang Pemilukada dari Harian Waspada Sumber: Harian Waspada

Struktur teks berita dalam gambaran berita ini adalah judul, teras, dan tubuh. Berita ini ditampilkan sebagai headline halaman utama, Harian Analisa dan Harian Waspada meletakkan berita atau peristiwa tersebut pada halaman depan koran, maka pemberitaan tentang dua bakal calon bupati Tapsel resmi daftar ke PPP dianggap penting. Suatu media menaruh sebuah berita atau peristiwa yang terjadi di headline, diasumsikan peristiwa tersebut pasti memperoleh perhatian besar dari khalayak. Setiap peristiwa yang dianggap dapat menarik minat pembaca, selalu dijadikan headline atau diletakkan pada halaman muka surat kabar (Sobur, 2002: 167).

Melihat dari penggunaan headline di atas, yang berjudul "Dua Bakal Calon Bupati Tapsel Resmi Daftar ke PPP" dapat memberikan pesan bahwa Syahrul M Pasaribu serius dalam pencalonannya pada Pemilukada Desember 2015 hal ini terbukti dari seluruh berkas persyaratan menjadi kandidat calon Pemilukada sudah diberikan kepada Ketua DPC PPP. Judul digunakan untuk menunjukkan bagaimana wartawan mengonstruksi suatu isu, seringkali dengan menekankan makna tertentu lewat pemakaian tanda bahasa untuk menunjukkan suatu perubahan atau untuk menunjukkan adanya jarak perbedaan (Eriyanto, 2002:258).

Apabila dilihat dari teras berita yang digunakan yaitu dua bakal calon bupati Tapanuli Selatan (Tapsel) yakni M. Pasaribu dan Muhammad Yusuf Siregar telah resmi mendaftar ke DPC PPP di Jalan MT Haryono, Kampung Marancar, Kota Padangsidempuan, mereka mendaftar hari Kamis tanggal 9 bulan April pada pukul 18.00 WIB. Jenis teras berita yang digunakan adalah gabungan dari unsur $5 \mathrm{~W}+1 \mathrm{H}$. 
Pada tubuh berita menggambarkan adanya dua bakal calon yang berharap bahwa PPP mampu mengusung mereka menjadi salah satu calon Pemilukada pada Desember 2015, hal tersebut diungkapkan berdasarkan berberapa informasi dari Muhammad Yusuf Siregar tentang memprioritaskan pembangunan sumber daya manusia dan perbaikan ekonomi, sedangkan dari Syahrul M Pasaribu memiliki hubungan yang baik yang dibina selama ini dalam konteks pembangunan Tapsel. Berdasarkan hasil penelitian hal ini sudah sesuai dengan apa yang dianalisis pada tubuh berita di Harian Analisa bahwa memandang dan menilai seorang tokoh dari track record serta visi dan misinya Tubuh berita ini juga terdapat berita yang objektif sekaligus pencitraan dalam diri Syahrul M pasaribu dan Muhammad Yusuf Siregar sehingga berita ini menjadi perhatian dari ketua DPD Golkar, PPP, dan partai Gerindra. Namun pada berita di atas tidak terdapat gambar dari tokoh atau figur yang diberitakan, sehingga hal ini kurang menarik bagi sebagian khalayak dari partai untuk memilih berita tersebut menjadi berita yang diambil untuk suatu penilaian. Namun untuk berita yang ada di Harian Waspada terdapat gambar sehingga dapat menarik bagi khalayak pembaca.

Pada berita di Harian Analisa dan Harian Waspada di atas dapat kita lihat bahwa kaidah bahasa yang digunakan sudah menggunakan Bahasa Indonesia yang baku dan benar sehingga masyarakat umum yang membacanya mampu mengerti dan memahami akan isi berita sesuai dengan hasil penelitian.

Unsur-unsur pokok dalam berita ini meliputi unsur (Who) Syahrul M Pasaribu dan Muhammad Yusuf Siregar, (What) mendaftarkan diri ke partai PPP, (When) tanggal 10 April pukul 18.00 WIB, (Where) di kantor DPC PPP Jalan MT Haryono, Kampung Marancar, Kota Padangsidempuan, (Whom) ke PPP, (How) Syahrul M Pasaribu memiliki hubungan baik dengan PPP sedangkan Muhammad Yusuf Siregar memiliki visi dan misi dalam memprioritaskan pengembangan SDM dan perbaikan ekonomi kerakyatan. Pada struktur susunan berita ini terdiri dari Who, What, Where, When, Whom dan How sehingga unsur $5 \mathrm{~W}+1 \mathrm{H}$ pada berita ini sudah lengkap dan sesuai dengan hasil penelitian.

Berita dari Harian Analisa dan Harian Waspada yang memberitakan tentang Pemilukada termasuk pada berita langsung (Straight News), karena berita ini langsung disajikan kepada masyarakat ketika wartawan mengumpulkan data dan faktanya di lapangan.

\section{Simpulan}

Media cetak nasional yang terdistribusi di tingkat kabupaten, provinsi, pusat dan memiliki basis pembaca yang besar seperti Harian Analisa dan Harian Waspada menjadi alat ukur partai politik dalam menilai elektabilitas bakal calon bupati yang akan diusungnya pada Pemilkukada Tapsel 9 Desember 2015. Isi berita yang memuat riwayat hidup, visi-misi dan kedekatan bakal calon kepala daerah dengan masyarakat menjadi salah satu faktor di luar lobi dan uang yang mampu mempengaruhi partai politik mengusung calon pada Pemilukada Tapsel. 


\section{Referensi}

Amal, Ichlasul. 1998. Teori-Teori Mutakhir Partai, Yogyakarta: PT. Tiara Wacana

Ardianto, E.L. 2004. Komunikasi Massa: Suatu Pengantar. Bandung: Simbiosa Rekatama Media.

Arikunto, Suharsimi. 1998. Prosedur Penelitian Suatu Pendekatan Praktek. Jakarta: Rineka Cipta

Black, James A dan Dean J Champion. 1999. Metode dan Masalah Penelitian Sosial. Bandung: Refika Aditama.

Budiarjo, Miriam. 2006. Dasar-Dasar Ilmu Politik, Jakarta: Gramedia Pustaka Utama.

Bungin, B., 2003. Penelitian Kualitatif. Jakarta: Prenada Media Group.

Creswell, John W. 2010. Research Design Pendekatan Kualitatif, Kuantitatif, dan Mixed.Yogyakarta: Pustaka Pelajar

Miriam Budiardjo. 2000. Dasar-Dasar Ilmu Politik. Jakarta: Gramedia Pustaka Utama.

Effendy, Onong Uchjana. 2003. Ilmu Teori \& Filsafat Komunikasi. Bandung: Citra Aditya Bakti

Effendy, Onong uchjana. 2006. Ilmu Komunikasi; Teori dan Praktek. Bandung: Penerbit Remaja Rosda Karya.

Firmanzah, Ph.D. 2008. Mengelola Partai Politik. Jakarta: Yayasan Obor Indonesia.

Kriyantono, Rachmat. 2006. Teknik Praktis Riset Komunikasi. Jakarta

Kencana Prenada Group.

Liliweri, Alo. 2010. Strategi Komunikasi Masyarakat. Yogyakarta: PT LKIS Printing Cemerlang.

Moleong, L. J. 2011. Metodologi Penelitian Kualitatif. Bandung: Remaja Rosdakarya

Mulyana, Deddy. 2005. Ilmu Komunikasi Suatu Pengantar. Bandung: Remaja Rosdakarya

Nasution. 1998. Metodologi Penelitian Naturalistic. Bandung: PN. TARSITO

Rakhmat, Jalaluddin. 2001. Psikologi Komunikasi. Bandung: PT Remaja Rosdakarya.

Sugiyono. 2007. “Metode Penelitian Kuantitatif Kualitatif dan R\&D”. Bandung: Alfabeta

Sugiyono. 2012. Metode Penelitian Pendidikan: Pendekatan Kuantitatif,

Kualitatif, dan R\&D. Bandung: Alfabeta.

Suprapto, Tommy. 2006. Pengantar Teori Komunikasi. Yogyakarta : Media Pressindo

), indeks merupakan salah satu sarana penelusuran literatur yang memberikan petunjuk tentang karya tulis apa saja yang telah diterbitkan dalam berbagai majalah atau dokumen bentuk lain mengenai subjek tertentu, berisi informasi mengenai subjek karya tulis tersebut, pengarang, penyunting (kalau ada), judul, sumber (kalau berbentuk majalah) dan sebagainya.

\section{Keluarga}

Pengertian Keluarga menurut BKKBN (1999), "Keluarga adalah dua orang atau lebih yang di bentuk berdasarkan ikatan perkawinan yang sah, mampu memenuhi kebutuhan hidup spiritual dan materil yang layak, bertakwa kepada Tuhan, memiliki hubungan yang selaras dan seimbang antara anggota keluarga dan masyarakat serta lingkungannya.

Barbaret (2004) menyatakan bahwa hubungan yang erat antara orangtua dengan remaja dapat menjadi penghalang terhadap perilaku meyimpang remaja. Begitu juga penelitian yang dilakukan oleh Klien at Al (1997) yang mendapatkan bahwa komunikasi 
antara ibu dan anak adalah salah satu variabel yang mempunyai hubungan dengan peningkatan atau penurunan tingkat penyimpangan perilaku dikalangan remaja.

\section{Komunikasi Efektif}

Aspek-aspek efektivitas komunikasi antar pribadi yang diungkapkan oleh Devito di dalam Suranto (2011), yakni pertama keterbukaan (openness). Keterbukaan adalah sikap dapat menerima masukan dari orang lain, serta berkenan menyampaikan informasi penting kepada orang lain. Hal ini tidaklah berarti bahwa orang harus dengan segera membukakan semua riwayat hidupnya, tetapi rela membuka diri ketika orang lain menginginkan informasi yang diketahuinya. Sikap keterbukaan ditandai adanya kejujuran dalam merespon segala stimulasi komunikasi. Kedua, empati (empathy). Empati ialah kemampuan seseorang untuk merasakan seandainya menjadi orang yang diajak berkomunikasi, dapat memahami sesuatu yang sedang dialami orang lain, dapat merasakan apa yang dirasakan orang lain dan dapat memahami sesuatu persoalan dari sudut pandang orang lain melalui kacamata orang lain. Empati akan membuat seseorang lebih mampu menyesuaikan komunikasinya.

Ketiga, dukungan (supportivenness). Komunikasi antarpribadi yang efektif adalah hubungan dimana terdapat sikap mendukung, artinya masing-masing pihak yang berkomunikasi memiliki komitmen untuk mendukung terselenggaranya interaksi secara terbuka. Oleh karena itu respon yang relevan adalah respon yang bersifat spontan dan lugas. Dukungan ini lebih diharapkan dari orang terdekat yaitu keluarga. Kelima, rasa positif (positiveness). Sikap positif ditunjukkan dalam bentuk sikap dan perilaku. Seseorang harus memiliki perasaan positif terhadap dirinya, mendorong orang lain lebih aktif berpartisipasi dan menciptakan situasi komunikasi kondusif untuk interaksi yang efektif. Apabila seseorang berpikir positif tentang dirinya, maka akan berpikir positif juga terhadap orang lain, sebaliknya bila menolak diri sendiri, maka akan menolak orang lain. Bila seseorang memahami dan menerima perasaan-perasaannya, maka akan lebih menerima perasaan-perasaan sama yang ditunjukkan orang lain. Keenam, kesetaraan/kesamaan (equality). Kesetaraan ialah pengakuan bahwa kedua belah pihak memiliki kepentingan, kedua belah pihak sama-sama bernilai dan berharga serta saling memerlukan. Komunikasi antar pribadi akan lebih efektif bila suasananya setara, artinya harus ada pengakuan diam-diam bahwa kedua belah pihak (orangtua dan remaja) menghargai, berguna dan mempunyai sesuatu yang penting untuk disumbangkan. Kemampuan orangtua dalam melakukan komunikasi akan efektif jika orangtua dapat membaca dunia anaknya (selera, keinginan, hasrat, pikiran dan kebutuhan).

Perilaku adalah tindakan atau aktivitas dari manusia itu sendiri yang mempunyai bentangan yang sangat luas antara lain : berjalan, berbicara, menangis, tertawa, bekerja, kuliah, menulis, membaca, dan sebagainya. Dari uraian ini dapat disimpulkan bahwa yang dimaksud perilaku manusia adalah semua kegiatan atau aktivitas manusia, baik yang diamati langsung, maupun yang tidak dapat diamati oleh pihak luar (Notoatmodjo, 2003).

Perilaku remaja dinilai dari sisi positif (tersenyum benar-benar terhadap satu sama lain, memvalidasi ide-ide orang lain, membuat lelucon yang benar-benar ramah, dan mendengarkan orang lain) dan negatif (mengganggu orang lain, mengkritik ide-ide orang lain, dan muncul tidak tertarik pada apa yang dikatakan orang lain) dalam interaksi diadik. Indikator positif dan negatif dianggap secara terpisah seperti yang telah direkomendasikan oleh peneliti lain. sistem pengkodean standard ini telah menunjukkan validitas (Allen, Porter, \& McFarland, 2006;. Allen et al, 2007). 
Ada beberapa pengertian tentang perilaku menyimpang (Juvenile Delinquency) atau kenakalan remaja. Menurut M. Gold dan J. Petronio, kenakalan remaja diartikan sebagai tindakan oleh seseorang yang belum dewasa yang sengaja melanggar hukum dan yang diketahui oleh anak itu sendiri bahwa, jika perbuatan itu sempat diketahui oleh petugas hukum ia bisa dikenai hukuman (Sarwono, 2001).

Menurut Horton dan Hunt (1996), ciri-ciri yang bisa diketahui dari perilaku menyimpang sebagai berikut:

a. Suatu perbuatan disebut menyimpang bilamana perbuatan itu dinyatakan sebagai menyimpang.

b. Penyimpangan terjadi sebagai konsekuensi dari adanya peraturan dan penerapan sanksi yang dilakukan oleh orang lain terhadap si pelaku menyimpang.

c. Ada perilaku menyimpang yang bisa diterima dan ada yang ditolak.

d. Mayoritas remaja tidak sepenuhnya menaati peraturan sehingga ada bentuk penyimpangan yang relatif atau tersamar dan ada yang mutlak.

Berdasarkan hasil penelitian Jonaidi, Nanang dan Nurmanina (2013), ditemukan bentuk-bentuk perilaku menyimpang terjadi di SMA Pembangunan yaitu:

1. Berkelahi lingkungan sekolah

2. Berpakaian tidak rapi di sekolah.

3. Membolos dari kegiatan sekolah.

4. Membawa ke sekolah barang yang tidak ada hubungannya dengan kegiatan Sekolah.

5. Terlambat masuk sekolah.

6. Merokok saat mengenakan pakaian sekolah di dalam kelas.

7. Minum-minuman keras (Miras) di sekolah maupun di luar sekolah.

8. Mengkonsumsi obat destro di sekolah.

Remaja

9. Menghisap lem lingkungan sekolah.

Hurlock (1999) membagi masa remaja menjadi dua bagian yaitu masa remaja awal 13-16 tahun dan remaja akhir 17-18 tahun. Ketentuan peraturan perundang-undangan menentukan batas usia seseorang belum dewasa adalah dibawah 18 tahun, (UU tentang HAM, UU No. 3 tahun 1997 tentang Pengadilan Anak, UU No. 23 tahun 2002 tentang Perlindungan Anak).

Menurut WHO (2012) dan Pinem (2009), remaja adalah seseorang yang berusia 1019 tahun, sedangkan menurut Soetjiningsih (2004) remaja berusia 11-20 tahun yang dibagi menjadi 3 tahap remaja awal (11-13 tahun), remaja tengah (14-16 tahun), dan remaja akhir (17-20 tahun).

\section{Teori S-O-R}

Teori S-O-R (Stimulus Organisme Respon) mengemukakan bahwa tingkah laku sosial dapat dimengerti melalui suatu analisis dari stimulus yang diberikan dan mempengaruhi reaksi yang spesifik dan didukung oleh hukum maupun penghargaan sesuai

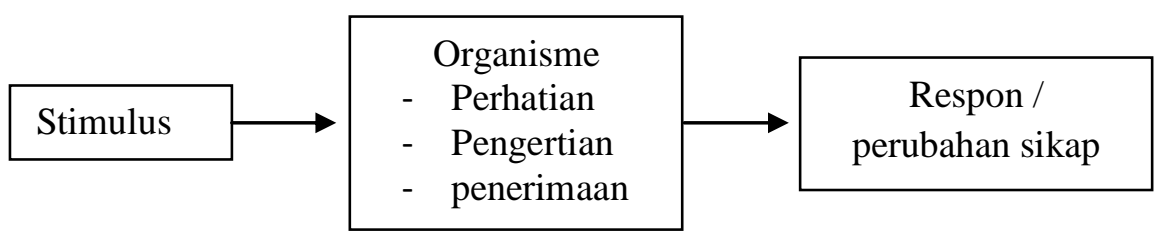

Gambar 2.1. Model Teori S-O- 
dengan reaksi (Rakhmat, 2004: 59). Teori ini mendasarkan asumsi bahwa penyebab terjadinya perubahan perilaku tergantung kepada kualitas rangsang (stimulus) yang berkomunikasi dengan organisme, baik dalam bentuk verbal maupun non-verbal. Artinya kualitas dari sumber komunikasi (sources) misalnya kredibilitas, kepemimpinan, gaya berbicara, sikap dan perilaku penyampai pesan itu sendiri sangat menentukan keberhasilan perubahan perilaku seseorang, kelompok atau masyarakat.

\section{Komunikasi Keluarga}

Komunikasi berasal dari bahasa Inggris "communication”, secara etimologis atau menurut asal katanya adalah dari bahasa Latin communicatus, berasal dari kata communis. Dalam kata communis ini memiliki makna 'berbagi' atau 'menjadi milik bersama' yaitu suatu usaha yang memiliki tujuan untuk kebersamaan atau kesamaan makna.

Komunikasi keluarga merupakan interaksi yang terjadi dalam lingkungan keluarga berupa penyampaian pesan baik verbal maupun non verbal sehingga memicu perilaku pada bagian-bagian dalam keluarga, dimana bagian tersebut dalam proses pencarian jati diri. Dalam hal ini remaja lah yang sangat cepat menilai komunikasi keluarga yang dialami, sehingga eksplorasi sangat cepat dilakukan di lingkungan baik dalam keluarga maupun di luar keluarga ditambah lagi penggunaan alat teknologi informasi dan komunikasi yang memerlukan perhatian khusus dalam pemanfaatannya.

\section{Kerangka Konsep}

Variabel Independen

Komunikasi Keluarga

1. Aspek komunikasi efektif

2. Komunikasi remaja dengan orangtua

3. Komunikai remaja dan saudara

\section{Variabel Dependen}

Perilaku Menyimpang Remaja

1. Berkelahi lingkungan sekolah

2. Berpakaian tidak rapi di sekolah.

3. Membolos dari kegiatan sekolah.

4. Membawa ke sekolah barang yang tidak ada hubungannya dengan kegiatan Sekolah.

5. Terlambat masuk sekolah.

6. Merokok saat mengenakan pakaian sekolah di dalam kelas.

7. Minum minuman keras (Miras) di sekolah maupun di luar sekolah.

8. Mengkonsumsi obat destro di sekolah.

9. Menghisap lem di lingkungan sekolah.

Gambar 2.2. Kerangka Konsep

\section{Metode}


Penelitian ini menggunakan metode kualitatif dan kuantitatif. Penelitian ini merupakan penelitian dengan pendekatan kuantitatif karena penelitian ini bersifat korelasional antara dua variabel (John, Zechmeister, \& Zechmeister 2006) yaitu untuk mengetahui hubungan yang positif antara komunikasi keluarga dan perilaku remaja. Teknik pengumpulan data melalui wawancara mendalam kepada pakar sebagai infromasi tentang kualitas komunikasi keluarga menggunakan pendekatan kualitatif diamana hasil wawancara digunakan sebagai tambahan dalam pembentukan instrument pertanyaan dalam kuesioner. Populasi diambil dari remaja berumur 13-16 tahun yang sedang mengikuti pendidikan di Sekolah Menengah Pertama (SMP) Hikmatul Fadhillah Medan yang akan dipilih menjadi responden penelitian. Daftar responden akan diperoleh langsung dari SMP Hikmatul Fadhillah Medan.

Menurut Bird, Gould, \& Staghezza (1992), We chose a self-report measure because of consensus that adolescents are the most valid reporters of their own internalizing problems. Kami memilih ukuran laporan diri karena konsensus bahwa remaja adalah wartawan yang paling valid dari masalah intern mereka. (Bird, Gould, \& Staghezza, 1992). Teknik pengumpulan data dalam penelitian ini menggunakan:

1. Wawancara (interview) langsung kepada pakar seperti ; Dosen, guru BP, Kepala Sekolah SMP Hikmatul Fadhillah Medan serta beberapa ahli yang dianggap berkompeten dalam penelitian ini.

2. Angket, yaitu dengan cara menyebarkan daftar pertanyaan berupa kuesioner, dimana dalam setiap pertanyaan tersedia empat alternatif jawaban.

3. Dokumentasi dilakukan dengan mengumpulkan dan mempelajari data-data pendukung berupa, struktur organisasi, daftar nama siswa serta perekaman kegiatan penelitian.

4. Studi literatur dilakukan dengan mengumpulkan dan mempelajari konsep, teori dan hasil penelitian yang berasal dari perpustakaan dan jurnal penelitian.

Uji t bertujuan untuk melihat pengaruh variabel bebas yaitu komunikasi keluarga sebagai strategi menangani perilaku menyimpang remaja pada siswa SMP Hikmatul Fadhillah. Menurut Sugiyono (2008:184), rumusannya sebagai berikut :

$$
\begin{array}{ll}
\text { Dimana : } \\
\mathrm{t} & =\text { nilai uji } \mathrm{t} \\
\mathrm{r}_{\mathrm{xy}} & =\text { nilai korelasi product moment } \\
\mathrm{n} & =\text { banyaknya sampel }
\end{array}
$$

\section{Hasil dan Pembahasan}

$$
t=\frac{r_{x y} \sqrt{n-2}}{\sqrt{1-\left(r_{x y}\right)^{2}}}
$$

Berdasarkan hasil jawaban kuesioner dapat disimpulkan bahwa pada SMP Hikmatul Fadhillah Medan terdapat perilaku menyimpang tetapi masih dalam kategori kecil, walaupun dalam jumlah kecil, perilaku menyimpang pada remaja memerlukan perhatian khusus dari pihak sekolah terutama dalam keluarga agar tidak semakin meningkat penyimpangannya dan penyebarannya kepada remaja yang lain. 
Analisis data penelitian dilakukan secara kualitatif pada sumber data yang digunakan sebagai tambahan instrument pembentukan kuesioner yang akan digunakan untuk analisis secara kuantitatif diperoleh dari wawancara pada pakar atau ahli dalam bidang yang berhubungan dengan pada penelitian ini.

1. Komunikasi Keluarga (Variabel X)

Komunikasi keluarga adalah komunikasi yang berlangsung dalam lingkungan keluarga. Menurut Firman (2014) bahwa komunikasi keluarga adalah komunikasi yang berlangsung dalam lingkungan keluarga secara terus menerus agar dapat membentuk kedekatan antar anggota keluarga, seperti berbicara santun dan pemberian nasehat.

Kualitas komunikasi keluarga bukan seberapa lama seseorang berkomunikasi dalam keluarga, tetapi seberapa besar manfaat dan sisi edukasi yang terkandung dari komunikasi yang berlangsung (Sunaryo : 11-4-2014). Kualitas komunikasi keluarga dapat tercermin pada sikap dan tingkah laku keseharian, namun hanya sebagian kecil yang dapat lihat. Dalam keluarga, bukan hanya keharmonisan yang menjadi tolak ukur kualitas komunikasi keluarga, namunkonflik yang terjadi dan dialami anak khususnya remaja juga menjadi hal penting untuk meningkatkan kedewasaan, selama konflik yang terjadi masih dalam pengawasan orangtua dan dapat diselesaikan dengan cepat.

Konflik yang berkepanjangan juga dapat mempengaruhi kognitif remaja. Firman (13-4-2014) menambahkan :Konflkik dalam keluarga tidak dikatakan perlu, tetapi memang ada dan pasti terjadi. Karena dengan adanya konflik itulah kedua belah pihak antara kakak dan adik dapat instrospeksi diri, sehingga harus melibatkan orang tua untuk memberikan pengarahan dan wejangan agar tidak berkepanjangan. Orang tua juga akan mengerti akan permasalahan dan kebutuhann yang mendesak sehingga menimbulkan konflik.

\section{Perilaku Menyimpang Remaja (Variabel Y)}

Perilaku menyimpang remaja adalah perilaku dan sikap yang tidak seharusnya dilakukan remaja, apa lagi menjadi rutinitas. Perilaku dikatakan menyimpang apabila sudah tidak dalam batasan atau norma-norma yang berlaku dilingkungan sekitar dan norma-norma yang berlaku pada remaja khususnya. Ada beberapa perilaku menyimpang remaja terutama usia tingkat sekolah menengah pertama yang diperoleh dari hasil wawancara kepada para pakar dan ahli yang berhubungan dengan penelitian ini, di antaranya :

$\begin{array}{ll}- & \text { Pergaulan bebas } \\ - & \text { Tawuran } \\ - & \text { Merokok } \\ - & \text { Minum minuman keras } \\ - & \text { Menghisap Lem } \\ - & \text { Menonton film porno }\end{array}$

- Berkelahi

- Telat pulang kerumah

- Berpakaian tida rapi

- Tidak disiplin

- Membawa benda tajam kesekolah

Beberapa contoh perilaku menyimpang tersebut merupakan hasil pergaulan remaja dengan lingkungan, tidak semua remaja terjerumus pada pergaulan ini. Manusia merupakan makhluk sosial sehingga cara remaja berbaur dilingkungan tidak bisa sepenuhnya dipantau oleh orang tua, namun orangtua dapat meminimalisir tingkat penyimpangan perilaku dengan cara menanamkan nilai-nilai yang benar berupa suatu kebiasaan dan ditanamkan dengan sadar, tidak boleh ada pemaksaan tentunya melalui pemahaman agama kemudian komunikasi yang santun, komunikasi yang menyenangkan, silaturahmi saling menyayangi, waktu berssama, misal makan bersama, jalan-jalan serta menjelaskan sanksi dan efek dari hal yang dilakukan baik perilaku baik maupun menyimpang, seperti halnya yang diterapkan pada perusahaan dengan memberlakukannya reward and punishment.

Sentuhan fisik yang dilakukan seperti menepuk bahu sambil memberikan nasehat atau memberikan "tamparan kecil" dengan ekspresi non verbal dan tidak menyakitinya sesuai dengan 
aturan semata-mata bukan karena emosi. Cara ini dapat memperkecil kemungkinan terjadinya perilaku menyimpang yang dipicu lingkungan atau bahkan dari keluarga itu sendiri.

\section{Simpulan}

Hasil penelitian teridentifikasi berdasarkan keterbukaan (openness) masih perlu ditingkatkan, karena komunikasi yang kurang terbuka akan membentuk perilaku anak untuk menghindar bahkan menjauh dari orangtua. Sebagian besar anak kadang-kadang menghindar jika orangtua sedang sibuk, hal ini menunjukan sikap empati (empathy) yang perlu lebih ditanamkan. Dukungan (supportivenness) orangtau terhadap anak sudah berjalan dapat terlihat dari hasil jawaban kuesioner yang lebih bnayak orangtua memberi izin akan hal-hal yang berprestasi. Rasa positif (positiveness) sangat erat dengan dukungan sehingga perlu kepada orangtua untuk berpartisipasi pada kegiatan yang dilakukan remaja. Saling menghargai dan menghormati baik terhadap yang lebih muda maupun yang lebih tua serta saling bercerita merupakan kesetaraan/kesamaan (equality) yang terjadi dalam komunikasi keluarga. Kualitas komunikasi keluarga yang berlangsung sudah baik, hal ini teridentifikasi berdasarkan hasil kuesioner yang telah dijawab.

Pada siswa SMP Hikmatul Fadhillah Medan terdapat perilaku menyimpang remaja, namum dalam jumlah dan persentase yang kecil. Komunikasi keluarga dengan perilaku menyimpang sangat berhubungan karena semakin baik komunikasi yang berlangsung maka semakin kecil kemungkinan terjadi perilaku menyimpang pada remaja. Pengaruh terhadap perilaku ini memperkuat teori S-O-R (Stimulus Organisme Respon) yang mengemukakan bahwa tingkah laku sosial dapat dimengerti melalui suatu analisis dari stimulus yang diberikan dan mempengaruhi reaksi yang spesifik dan didukung oleh hukum maupun penghargaan sesuai dengan reaksi (Rakhmat, 2004: 59).

\section{Referensi}

Abiyoso, Octo J., (2012). Hubungan Efektifm Komunikasi Antarpribadi dalam Keluarga dengan Motivasi Belajar Anak di Sekolah. eJurnal Mahasiswa Universitas Padjadjaran, Vol. 1., No.1.

Alias M, Fatmawati \& Mochtaria. (2013). Kontrol Sosial Tokoh Masyarakat (Ustad) dalam Mengatasi Penyimpangan Perilaki Remaja di Desa Limbung

Kecamatan Sungai Raya Kabupaten Kubu Raya. Jurnal tesis PMIS-UNTAN-PSS.

Allen, J. P., Porter, M., McFarland, F. C., McElhaney, K. B., Marsh, P. 2007. The relation of attachment security to adolescents' paternal and peer relationships, depression, and externalizing behavior. Child Dev. 2007 ; 78(4): 1222-1239.

Ardianto, Elvinaro. (2009). Public Relations Praktis. Bandung : Widya Pajajaran

Arikunto, Suharsimi. (2002). Metodologi Penelitian. Penerbit PT. Rineka Cipta. Jakarta.

Atmasasmita, Romli. (2005). Problema Kenakalan Anak-Anak dan Remaja, Bandung: Amico. 
Azten, I. 2005. The Theory Of Planned Behaviour. Organizational behavior and human discussion processes, Open University Press. 50, 179-211.

I. (2005). Attitudes, Personality and Behaviour. Second Edition. Open University Press.

Azwar, Azrul. 2002. Pengantar Epidemiologi. Jakarta Barat: Penerbit Binarupa Aksara. Edisi Revisi.

Barberet, R., Bowling B., Junger-Tas, J., Rechea-Alberola, C., Van Kasusteren, J. \& Zurawan, A. (2004). In self-report Juvenile Delinquency England and Wales, The Netherland and Spain. Publication Series No. 43, European Institute For Crime Prevention and Control.

Bobak. Lowdermilk. (2004). Buku Ajar Keperawatan Maternitas. Edisi keempat. Jakarta: EGC.

Bungin, Burhan. (2006). Sosiologi Komunikasi: Teori, Pradigma, dan Diskursus Teknologi Komunikasi di Masyarakat. Jakarta: Kencana Prenada Media Group.

Cangara, H. 2011. Pengantar Ilmu Komunikasi. Jakarta: Rajawali Pers.

Cheung, Y.W., (1997). Family, School, Peer, and Media Predictors of Adolescent Deviant Behavior in Hongkong. Jurnal Of Youth Adolescence, 26 (5), 569-595.

Clark, R.D. \& Shield, G., (1997). Family Comunication and Delinquency. Adolescence, 32 (125), 81-92.

Daryanto. (2011). Ilmu Komunikasi. Bandung: PT Sarana Tutorial Nurani Sejahtera.

Effendy, O. U. (2011). Ilmu Komunikasi “Teori dan Praktik". Bandung: PT. Remaja Rosdakarya. (2003). Ilmu, Teori dan Filsafat Komunikasi, Bandung : PT. Citra Aditya Bakti.

Gunawan, Hendri, (2013). Jenis Pola Komunikasi Orang Tua Dengan Anak Perokok Aktif Di Desa Jembayan Kecamatan Loa Kulu Kabupaten Kutai Kartanegara. eJournal Ilmu Komunikasi, 2013, 1 (3): 218-233.

Gunawati, R., Hartati, S., \& Listiara, A. (2006). Hubungan Antara Efektivitas Komunikasi Mahasiswa dan dosen Pembimbing Utama Skripsi Dengan Stres Dalam Menyusun Skripsi Pada Mahasiswa Program Studi Psikologi Fakultas Kedokteran Universitas Diponegoro. Jurnal Psikologi Universitas Diponegoro. Vol. 3, No. 2 : 93-115. 